\title{
HUBUNGAN ASI EKSKLUSIF TERHADAP PERKEMBANGAN ANAK USIA 6-12 BULAN DI PUSKESMAS PESURUNGAN LOR
}

\author{
Ratih Sakti Prastiwi ${ }^{1)}$, Ulfatul Latifah ${ }^{2)}$ \\ 1 Diploma III Kebidanan, Politeknik Harapan Bersama \\ email: ratih.sakti@ymail.com \\ 2 Diploma III Kebidanan, Politeknik Harapan Bersama
}

\begin{abstract}
Abstrak
ASI Eksklusif merupakan salah satu faktor penting yang mempengaruhi perkembangan anak lebih optimal. Tingginya aktifitas ibu diluar rumah menjadi kendala untuk memberikan ASI secara Eksklusif dan cenderung memberikan formula. Capaian ASI Eksklusif di wilayah Pesurungan Lor $<60 \%$, hal ini dapat mempengaruhi pencapaian pertumbuhan dan perkembangan bagi anak di wilayah tersebut. Penelitian ini dilakukan untuk melihat apakah terdapat pengaruh pemberian ASI Eksklusif pada anak usia 6-12 terhadap perkembangannya. Metode yang digunakan adalah penelitian deskriptif terhadap anak usia 6-12 bulan. Teknik sampling diambil menggunakan teknik accidental sampling dan didapatkan sampel sebanyak 26 sampel. Data dikumpulkan menggunakan instrumen Kuesioner Pra Skrining Perkembangan (KPSP). Data selanjutnya dianalisis menggunakan chi-square test. Hasil analisis didapatkan terdapat hubungan antara pemberian ASI Eksklusif dengan perkembangan anak namun tidak signifikan ditunjukkan dari adanya $\rho$-value sebesar 0.09. Perkembangan anak tidak hanya dipengaruhi oleh pemberian ASI Eksklusif saja, namun terdapat faktor lain seperti emotional bonding serta adanya pemberian stimulus dari orang tua atau pengasuh anak.
\end{abstract}

Kata kunci : ASI Eksklusif, perkembangan, anak, bayi

\begin{abstract}
Exclusive breasfeeding was an important aspect in children development. For working mothers, breast feeding exclusively would be hard and they prefer to used formula. Exclusive breastfeeding coverage in Pesurungan lor were less than 60\%, it could cause an impending for growth and development in children achievement. The purpose of this study was to assess relation of breastfeeding exclusively with 6-12 months baby's development. This study used descriptive analytichal method. Using accidental sampling to babies aged 0-6 months (26 babies). Data collected using Kuesioner Pra Skrining Perkembangan (KPSP) and analyzed using chi-square test. This study show there is a relation within breastfeeding exclusively and children development but not significant ( $\rho$-value: 0.09). Children development not only influenced by breast milk but it could be influence by emotional bonding and/or stimulation by their parents or their caretakers,
\end{abstract}

Keywords : Exclusive breastfeeding, development, children, babies

\section{PENDAHULUAN}

Usia di bawah lima tahun merupakan periode keemasan seorang anak mengalami tumbuh kembang yang optimal. Kejadian gangguan perkembangan anak usia balita di Indonesia saat ini mencapai 3 juta anak. Gangguan perkembangan yang banyak dilaporkan antara lain perkembangan otak, pendenggaran dan gangguan motorik. Secara umum, gangguan pertumbuhan dan perkembangan anak di Indonesia mencapai
$35,7 \%$ dan menjadi salah satu masalah yang perlu di prioritaaskan menimbangkan target yang ditetapkan WHO batas minimal kejadian gangguan adalah 30\% (Gunawan et. al., 2011; Maharani et. al., 2018).

Seorang anak dapat tumbuh dan berkembang secara optimal apabila anak mendapatkan asupan gizi yang baik. Pemenuhan gizi pada anak usia 0-6 bulan didapatkan melalui pemberian ASI. Beberapa penelitian di dunia memberikan 
banyak bukti bahwa pemberian ASI secara eksklusif memberikan banyak manfaat pada anak seperti pencegahan terjadinya infeksi gastrointestinal, otitis media, serta mempengaruhi perkembangan intelegensi dan performa akademik yang optimal pada anak usia sekolah. ASI Eksklusif juga dapat mempengaruhi perkembangan kognitif, sosial dan emosional anak baik langsung dari nutrisi tertentu yang dikandung dalam ASI atau interaksi ibu saat menyusui. Anak dapat memiliki perkembangan yang positif apabila sejak dini telah memiliki kognitif, sosial dan emosional yang baik (Setyarini, 2015; Belfort et.al., 2016).

ASI mengandung dua tipe asam lemak yang bekerja secara spesifik yaitu docosahexaenoic (DHA) dan arachidonic acid. Kedua senyawa tersebut memiliki pengaruh terhadap perkembangan dan pematangan saraf yaitu perkembangan kognitif anak seperti perkembangan bahasa anak. Anak yang tidak mendapatkan ASI cenderung mengalami perkembangan yang menyimpang dibandingkan dengan mereka yang mendapat ASI. Anak mengalami keterlambatan motorik kasar sebesar 30\% dan motorik halus sebesar $40 \%$. (Solihin et.al., 2013; Triyani et. al., 2014; Girard et.al., 2017).

Cakupan ASI di Indonesia mengalami penurunan, pada tahun 2013 cakupan ASI Eksklusif mencapai 38\% dan turun menjadi $29.5 \%$ pada tahun 2015. Cakupan di Jawa Tengah sendiri cukup jauh dari target nasional, pada tahun 2016 cakupan ASI Eksklusif sebesar $42.7 \%$. Kota Tegal merupakan salah satu kotamadya di wilayah Jawa Tengah yang memiliki cakupan yang rendah yaitu sebesar 23.8\%. Puskesmas Pesurungan lor merupakan salah satu Puskesmas di Kota Tegal dengan capaian cakupan $<60 \%$.

Mayoritas ibu di wilayah Pesurungan Lor merupakan ibu yang bekerja sehingga memerlukan waktu yang cukup lama untuk meninggalkan bayinya. Hal ini menjadi kendala ibu untuk memberikan ASI secara eksklusif dan cenderung menggantikannya dengan susu formula. Tujuan dilakukannya penelitian ini adalah untuk melihat pengaruh pemberian ASI secara eksklusif pada anak usia 6-12 bulan terhadap perkembangannya.

\section{METODE PENELITIAN}

Penelitian ini merupakan penelitian kuantitatif deskriptif. Penelitian dilakukan di Posyandu wilayah Pesurungan Lor. Sampel diambil menggunakan teknik accidental sampling, yaitu dengan mengambil responden yang memenuhi kriteria yang ditetapkan oleh peneliti dan ditemui pada saat pelaksanaan penelitian berlangsung yaitu, usia anak 6-12 bulan dan ibu bersedia menjadi responden penelitian. Penelitian dilakukan pada bulan Desember 2017 dan berakhir pada bulan Januari 2018 dan didapatkan sampel sebanyak 26 responden (Etikan et.al., 2016).

Pengumpulan data menggunakan instrumen penelitian berupa Kuesioner Pra Skrinning Perkembangan (KPSP) dan formulir biodata responden. KPSP merupakan alat skrining yang dikeluarkan oleh Departemen Kesehatan bekerja sama dengan Ikatan Dokter Anak Indonesia (IDAI) tahun 2005. KPSP berisi pertanyaan mengenai perkembangan anak dikelompokkan berdasarkan usia. KPSP memiliki sensitivitas 95\% dan spesifitas sebesar $63 \%$ sehingga dapat memberikan hasil yang signifikan (Susanty et. al., 2014; Wani et. al., 2017).

Peneliti menggunakan teknik wawancara untuk mendapatkan data identitas ibu dan bayi serta riwayat pemberian ASI pada bayi. Peneliti juga melakukan uji tumbuh kembang menggunakan kuesioner KPSP. Perkembangan anak yang dinilai meliputi perkembangan motorik halus, motorik kasar, kemampuan bicara dan bahasa serta kemampuan sosialisasi dan kemandirian. Data yang didapatkan kemudian dilakukan analisis menggunakan chi-square untuk melihat hubungan antara pemberian ASI Eksklusif dengan perkembangan anak usia 6-12 bulan.

\section{HASIL DAN PEMBAHASAN}

Penelitian ini dilakukan untuk melihat adakah pengaruh dari pemberian ASI secara eksklusif pada bayi terhadap perkembangan bayi usia 6-12 bulan. Adapun gambaran responden dalam penelitian ini dapat dilihat pada tabel 1 . 
Tabel 1. Karakteristik responden

\begin{tabular}{lcc}
\hline Karakteristik & f & \% \\
\hline Usia Anak & & \\
6-8 bulan & 20 & 71.4 \\
9-12 bulan & 8 & 28.6 \\
& & \\
ASI Eksklusif & & \\
Ya & 16 & 57.1 \\
Tidak & 12 & 42.9 \\
\hline
\end{tabular}

Jumlah responden yang mendapatkan Asi Eksklusif dan tidak mempunyai perbandingan yang hampir sama. Data tersebut dapat membantu untuk memastikan bahwa ada tidaknya pengaruh ASI Eksklusif terhadap perkembangan anak. ASI Eksklusif merupakan bentuk pemberian ASI yang diberikan sejak bayi lahir hingga usia enam bulan tanpa diberikan tambahan apapun seperti makanan atau minuman pengganti kecuali obat (Yuliarti, 2010).

Perilaku tidak memberikan ASI Eksklusif cukup tinggi. Dari hasil wawancara diketahui anak pada usia rentang 0-6 bulan pernah mendapatkan makanan tambahan seperti pisang, meskipun anak memuntahkannya. Pemberian makanan tambahan tersebut cenderung dilakukan oleh keluarga khususnya nenek.

Ketidakberhasilan pemberian ASI juga dipengaruhi oleh persepsi ibu terhadap kecukupan ASInya. Persepsi tersebut mempengaruhi ibu untuk cenderung memberikan susu formula. Adanya peningkatan iklan baik media massa maupun media elektronik yang mempromosikan susu formula dengan kemasan yang cukup menarik, meningkatkan minat ibu untuk memberikan susu formula dengan harapan susu formula mampu memenuhi nutrisi yang dibutuhkan (Prabasiwi et. al, 2015; Alamsyah et.al., 2017).

Penilaian perkembangan anak menggunakan KPSP sesuai dengan rentang usia sebagaimana disebutkan dalam tabel 1 . Hasil penilaian perkembangan anak disajikan pada tabel berikut:

Tabel 2. Hasil Penilaian Perkembangan Anak

\begin{tabular}{lcc}
\hline Perkembangan & f & \% \\
\hline Sesuai & 26 & 92.9 \\
Meragukan & 2 & 7.1 \\
\hline
\end{tabular}

Pada tabel 2 diketahui mayoritas responden perkembangannya telah sesuai dengan usianya, namun masih terdapat $7.1 \%$ yang meragukan. Ditemukan perkembangan yang meragukan dapat dikarenakan anak merasa malu atau ragu saat bertemu dan berinteraksi dengan orang yang asing. Pada usia responden berkisar 6-12 bulan merupakan usia dimana anak sangat lekat dengan orang tua atau yang mengasuhnya. Hal tersebut mendorong anak muncul perasaan tidak percaya (mistrust) terhadap orang asing. Sehingga untuk memastikan bahwa perkembangan anak, maka perlu dilakukan penilaian kembali dalam waktu 2 minggu. Selama rentang waktu antara, anak diberikan intervensi sebanyak tiga kali dalam sehari selama 15-30 menit oleh orang tua atau pengasuh dan mencatatnya dalam kartu harian sehingga orang tua atau pengasuh dapat melihat peningkatan perkembangan anak. Pemberian intervensi tersebut perlu dilakukan dengan harapan anak dapat mencapai perkembangan sesuai dengan usianya. Apabila dalam dua minggu anak masih ditemukan penyimpangan maka intervensi dilakukan kembali selama dua minggu (Susanty et. al, 2014; Nurhayati, 2015).

Tabel 3. Uji Hubungan Pengaruh ASI Eksklusif terhadap Perkembangan Anak

\begin{tabular}{lcc}
\hline & \multicolumn{2}{c}{ Tumbuh Kembang } \\
\cline { 2 - 3 } & Sesuai & Meragukan \\
\hline ASI Eksklusif & $16(61,5 \%)$ & $0(0,0 \%)$ \\
Tidak ASI & $10(38,5 \%)$ & $12(42,9 \%)$ \\
\hline
\end{tabular}

Pada tabel 3 diketahui anak yang mendapatkan ASI Eksklusif mayoritas memiliki perkembangan sesuai dengan usianya. Dari hasil uji hubungan didapatkan $\rho$-value 0.90 dan dapat disimpulkan pengaruh ASI Eksklusif terhadap perkembangan anak tidak significant. Pada tabel 3 diketahui 38,5\% anak yang tidak mendapatkan ASI secara Eksklusif memiliki perkembangan yang normal. Triyani et. al. (2014), dalam penelitiannya menyebutkan bahwa anak yang mendapatkan ASI secara eksklusif lebih dari 4 bulan memiliki perkembangan yang normal. 
Pemberian ASI Eksklusif menurut Peraturan Pemerintah Republik Indonesia Nomor 33 tahun 2012 adalah memberikan ASI kepada bayi sejak bayi dilahirkan hingga usia 6 bulan tanpa menambah atau mengganti dengan makanan lain atau minuman lain kecuali suplemen vitamin, obat maupun mineral. Dari penjelasan tersebut dapat diasumsikan pula responden dalam penelitian ini sebelumnya telah mendapatkan ASI penuh hingga 4 bulan, namun dalam perjalanannya terdapat penambahan makanan atau minuman selain ASI sehingga tidak dapat dikategorikan sebagai ASI Eksklusif.

Dalam penelitian Imani dan Hardaningsih (2017) menjelaskan bahwa susu formula tidak mempengaruhi perkembangan motorik kasar, motorik halus, maupun bahasa sesuai dengan perkembangan usia. Jenis susu formula yang diberikan baik berupa susu protein sapi maupun susu protein kedelai juga tidak mempengaruhi perkembangan anak.

Perkembangan anak dapat dipengaruhi faktor lainnya seperti adanya emotional bonding antara anak dengan lingkungan sekitar. Dengan menyusu muncul rasa lekat dan aman pada bayi di tahun pertama dan kedua kehidupannya yang secara langsung dapat mempengaruhi perkembangan anak khususnya pada aspek emosional. Dengan adanya kelekatan antara ibu dan anak juga mempengaruhi penerimaan stimulus yang

\section{REFERENSI}

Alamsyah D, Marlenywati, Ruthayana H. (2017). Hubungan antara Kondisi Kesehatan Ibu, Pelaksanaan IMD dan Iklan Susu Formula dengan Pemberian ASI Eksklusif. IKESMA, 13 (1)

Belfort M, Rifas-Shiman S, Kleinman K, Bellinger D, Harris $\mathrm{M}$, Taveras $\mathrm{E}$, Gillman M, Oken E. (2016). Infant Breastfeeding Duration and MidChildhood Executive Function, Behavior and Social-emotional Development. J Dev Behav Pediatr, 37(1): 43-52

Etikan I, Musa SA, Alkassim RS. (2016). Comparison og Convenience Samplin and Purposive Sampling. American diberikan oleh orang tua. Pemberian stimulasi secara rutin dan berkesinambungan serta dicurahkannya kasih sayang menggunakan metode yang menarik dapat meningkatkan potensi anak untuk berkembang secara optimal. Anak yang mendapatkan stimulasi sejak dini akan mengalami perkembangan otak mencapai $80 \%$ pada anak kuirang dari 4 tahun, sebaliknya pada anak yang tidak mendapatkan stimulasi yang baik maka jaringan dalam otak akan mengecil dan dapat mengakibatkan penurunan fungsi otak salah satunya terjadinya keterlambatan perkembangan. Sehingga meskipun anak tidak mendapatkan ASI Eksklusif selama 6 bulan, anak dapat berkembang sesuai dengan usianya (Setyarini et. al., 2015; Hati dan Lestari, 2016; Latifah et. al., 2010).

\section{KESIMPULAN DAN SARAN}

Jumlah bayi yang tidak mendapatkan ASI Eksklusif masih tinggi. Terdapat hubungan yang tidak signifikan antara pemberian ASI Eksklusif terhadap perkembangan anak usia 6-12 bulan.

Melihat masih sedikitnya pencapaian ASI Eksklusif, perlu adanya pemberian informasi terhadap keluarga atau pengasuh anak mengenai pentingnya ASI Eksklusif dan cara menstimulasi anak agar perkembangan sesuai dengan usianya.

Journal of Theoritical and Applied Statistics, 5 (1): 1-4

Girard L, Doyle O, Tremblay R. (2017). Breastfeeding, Cognitive and Noncognitive Development in Early Childhood: A Population Study. PEDIATRICS, 139 (4)

Gunawan G, Fadlyana E, Rusmil K. (2011). Hubungan Status Gizi dan Perkembangan Anak Usia 1-2 tahun. Sari Pediatri, 13(2): 142-146

Imani F dan Hardaningsih G. (2017). Pengaruh Pemberian Formula Hidrolisa Ekstensif dan Isolat protein Kedelai terhadap Perkembangan Anak dengan Alergi Susu Sapi di Kota Semarang. 
Jurnal Kedokteran Diponegoro, 6 (2): 530-540

Latifah E, Hastuti D, Latifah M. (2010). Pengaruh Pemberian ASI dan Stimulasi Psikososial terhadap Perkembangan Sosial-emosi Anak balita pada Keluarga Ibu Bekerja dan Tidak Bekerja. Jurnal Ilmu Keluarga dan Konsumen, 3(1): 3545

Maharani, Ayu S, Setiawan I. (2018). Hubungan Pemberian Asi Eksklusif, Jenis Kelamin dan Status Gizi terhadap Perkembangan Motorik Kasar Pada Anak Usia 3-5 tahun di Kelurahan Makam Haji. Thesis. Surakarta: Universitas Muhammadiyah Surakarta

Nurhayati H. (2015). Hubungan kelekatan Aman (Secure Attachment) Anak pada Orang Tua dengan Kemandirian Anak Pada Kelompok V TK PKK 37 Dodoganjatimulya Dlingo Bantul. Naskah Publikasi. Yogyakarta: Universitas negeri Yogyakarta

Prabasiwi A, Fikawati S, Syafiq A. (2015). ASI Eksklusif dan Persepsi Ketidakcukupan ASI. Kesmas: National Public Health Journal, 9 (3): 262-287

Setyarini A, Mexitalia M, Margawati A. (2015) Pengaruh Pemberian ASI Eksklusif dan Non Eksklusif terhadap Mental Emosional Anak Usia 3-4 Tahun. Medica Hospitalia, 3(1): $36-41$
Solihin, Malateki RD, Anwar F, Sukandar D. (2013). Kaitan antara Fizi, Perkembangan Kognitif, dan Perkembangan Motorik pada Anak Usia Prasekolah. Penelitian Gizi dan Makanan, 36 (1): 62-72

Tryani S, Meilan N, Purbowati. (2014). Hubungan antara Lama Pemberian ASI Eksklusif dengan perkembangan Anak Usia 12-36 Bulan. Jurnal Ilmu dan Teknologi Kesehatan, 1 (2): 113-119

Yuliarti, Nurheti. (2010). Keajaiban ASI Makanan Terbaik untuk Kesehatan, Kecerdasan, dan Kelincahan Si Kecil. Yogyakarta: CV. ANDI

Susanty A, Fadlyana E, Nataprawira H. (2014). Manfaat Intervensi Dini Anak Usia 6-12 bulan dengan Kecurigaan Penyimpangan Perkembangan. Majalah Kedokteran Bandung, 42(2): 63-67

Hati F dan Lestari P. 9. (2016). Pengaruh Pemberian Stimulasi pada Perkembangan Anak Usia 12-36 Bulan di Kecamatan Sedayu, Bantul. Journal Ners and Midwifery Indonesia, 4(1): 4448

Wani Y, Wilujeng C, Rahmi Y, Kusuma T, Rahmawati W, Fadhilah E, Ruhana A. (2017). Survei Status Gizi dan Perkembangan Anak Balita Menggunakan Kuesioner Praskrining Perkembangan (KPSP). Majalah Kesehatan FKUB, 4(4): 193-199 